\title{
Can normalized tissue activities be used instead of absolute blood flow measurements in the brain?
}

Kathleen Schmidt

Laboratory of Cerebral Metabolism, National Institute of Mental Health, Bldg 36, Rm 1A-07, 36 Convent Drive, Bethesda, MD 20892-4030, USA

Published online: 18 July 2002

(c) US Government 2002

Eur J Nucl Med (2002) 29:1268

DOI 10.1007/s00259-002-0943-x

\section{Eur J Nucl Med (2002) 29:953-956}

This article was originally published under the incorrect title "Can ROI methodology/normalised tissue activities be used instead of absolute blood flow measurements in the brain?" The position "Against" normalization was not a position against the use of ROI methodology; on the contrary, the author strongly advocates region of interest analyses for cerebral blood flow data.

The online version of the original article can be found at http:// dx.doi.org/10.1007/s00259-002-0838-x

Kathleen Schmidt (

Laboratory of Cerebral Metabolism,

National Institute of Mental Health, Bldg 36, Rm 1A-07,

36 Convent Drive, Bethesda, MD 20892-4030, USA

e-mail: kathy@shiloh.nimh.nih.gov

Tel.: +1-301-4023119, Fax: +1-301-4801668 